\title{
PHYTOCHEMICAL ANALYSIS AND ANTIBACTERIAL ACTIVITY OF IPOMOEA INDICA PLANT
} LEAF EXTRACTS

\author{
SEENU YUVARANI ${ }^{a}{ }^{*}$, SELVAMa \\ aDepartment of Botany, Periyar University, Salem, Tamilnadu, India India, ${ }^{2}$ Root and soil biology lab, Department of Botany, Bharathiar \\ University, Coimbatore \\ Email: yuvara695@gmail.com
}

Received: 28 Dec 2017, Revised and Accepted: 05 Feb 2018

\begin{abstract}
Objective: The objective of this study was to phytochemical analysis and antibacterial activity of the Ipomoea indica plant leaves extracts.

Methods: The crude powder of the plant leaf samples of $I$. indica was extracted using methanol and aqueous solvents and subjected to qualitative phytochemical analysis. The antibacterial activity of the aqueous and methanol extracts was tested at different for concentrations. The extract was tested against bacterial strains like Staphylococcus aureus, Enterococcus faecalis, Salmonella typhi, and Escherichia coli.

Results: The phytochemical screening revealed the presence of alkaloids, flavonoids, terpenoids, glycoside, reducing sugars, saponins, steroids and tannins in the solvent extract. The antibacterial activity was performed by using the disc diffusion method, where the largest zone of inhibition was obtained with aqueous extract $75 \mu$ concentration against Salmonella typhi $(26 \mathrm{~mm})$. The antibacterial activity was compared with the standard antibiotics like Streptomycin.
\end{abstract}

Conclusion: This study suggests that the aqueous extract of the $I$. indica leaves possesses bioactive compounds with antibacterial activity against the bacterial strains, which can be used to formulate new antibacterial drugs for disease control.

Keywords: Ipomoea indica, Phytochemical screening, Antibacterial activity, Disc diffusion

(C) 2018 The Authors. Published by Innovare Academic Sciences Pvt Ltd. This is an open access article under the CC BY license (http://creativecommons.org/licenses/by/4.0/] DOI: http://dx.doi.org/10.22159/ijcpr.2018v10i2.25879

\section{INTRODUCTION}

Plants are integral of nature. Nature reflects the creative power of living god. Plants as a source of medicine has been an ancient practice and is an important component of the health care system in India. Andaman, Nicobar Islands, Eastern Himalayas, and Western Ghats were concentrated region in more than 45,000 medicinal plants available in India. The traditional practitioners use more than 6000 medicinal plant, but officially 3000 species were documented $[1,2]$. According to the WHO, about $80 \%$ of the population in the world relay on the traditional medicine for the treatment of various diseases [3]. However, the development of new antibiotics should be continued as they are of primary importance to maintain the effectiveness of antimicrobial treatment [4]. Phytochemical, are natural compound occur in plants such as medicinal plants, vegetables and fruits that work with nutrients and fibers to act against diseases or more specifically to protect against diseases. The Phytochemicals are grouped into two main categories of [5] namely primary constituents which includes amino acids, chlorophyll, proteins and common sugars, etc., and secondary constituents consisting of alkaloids, essential oils, flavonoids, tannins, terpenoids, saponins, phenol compounds etc. [6, 7]. Ipomoea is one of the important plant genus there are great medicinal values and as we all know the second largest genus of Convolvulaceae family is Ipomoea with around 600 species. Ipomoea species are usually found in tropic or subtropical regions. Which are exclusively known for their therapeutic values such as Anti-inflammatory, alkaloids are known to have shown potential anticancer properties. Ipomoea indica is a species of flowering plant in the family Convolvulaceae. There are common known as 'Blue morning glory'. A number of species have been introduced in India and many species are grown in gardens for ornamental purpose. The medicinal properties of plants are attributed to the secondary metabolites synthesized in the plants and increasing attention has been directed towards the use of these for the treatment of many infectious diseases [8]. There has been an increasing incidence of multiple resistances in human pathogenic microorganisms in recent years, largely due to indiscriminate use of commercial antimicrobial drugs commonly employed in the treatment of infectious diseases. This has forced scientist to search for new antimicrobial substances from various sources like the medicinal plants. The present investigation was deals with the identification of bioactive compounds and to screen the antibacterial assay of Ipomoea indica plant.

\section{MATERIALS AND METHODS}

\section{Collection of plant materials}

The selected plant species namely I. indica leaves were collected from Kaligoundampalayam village in Salem District, Tamil Nadu, India. The collected samples were carefully stored in sterile polythene bags. Plant were identified Flora of the presidency of madras by J. S Gamble book from Department of Botany, Periyar University, Salem, Tamil Nadu, India.

Preparation of aqueous and methanol extract of Ipomoea indica

Plant leaves were shade dried at room temperature for $10 \mathrm{~d}$. The sample preparation was powdered by using a mechanical grinder. For aqueous extraction, $10 \mathrm{~g}$ of air-dried powder was placed in distilled water and boiled for $6 \mathrm{~h}$. At intervals of $2 \mathrm{~h}$ it was filtered through 8 layers of Whattman filter paper and centrifuged at 5000 $\mathrm{rpm}$ for $15 \mathrm{~min}$. The supernatant was collected. After $6 \mathrm{~h}$, the supernatant was concentrated to make the final volume one-fourth of the original volume. It was then autoclaved at 121 and stored at 4 . For methanol extract 10gram of powdered material were taken in five hundred capacity thimbles of Soxhlet apparatus and refluxed with methanol and water separately until all soluble compounds had been extracted. Extraction was considered to be complete when the filtrate had a faint colour. A portion of the residue was used for the phytochemical analysis and antibacterial assay.

\section{Preliminary phytochemical analysis}

Phytochemical study was performed to identify phytochemical in the methanol and water extracts of the plant leaves were used in the 
study in this present work, the phytochemical were detected by colour test.

\section{Test for alkaloids}

\section{Dragendorff's reagent test}

To 2 extract of plant leaves, $1 \mathrm{ml}$ of $1 \% \mathrm{Hcl}$ was added in a test tube, and heated in a water bath for $10 \mathrm{~min} .1 \mathrm{ml}$ solution was taken and 6 drops of Dragendorff's reagent mixed separately. Appearance of Orange precipitate, precipitate respectively indicates the presence of alkaloids.

\section{Test for tannins}

\section{Braymer's test}

$0.5 \mathrm{ml}$ of extract solution $1 \mathrm{ml}$ of distilled water and 1-2 drops of ferric chloride solution was added. Blue colour was observed for tannins and green black for catecholic tannins.

\section{Test for terpenoid}

\section{Salkowski test}

$4 \mathrm{ml}$ of extract was treated with $0.5 \mathrm{ml}$ of acetic anhydride and 0.5 $\mathrm{ml}$ of chloroform. Then concentrated solution of sulphuric acid was added slowly and red violet colour was observed for terpenoid.

\section{Test for steroids}

$4 \mathrm{ml}$ of extract was treated with $0.5 \mathrm{ml}$ of acetic anhydride and 0.5 $\mathrm{ml}$ of chloroform. Then concentrated solution of sulphuric acid was added slowly and green bluish colour for steroids.

\section{Test for reducing sugar}

\section{Fehling's test}

$0.5 \mathrm{ml}$ of extract solution $1 \mathrm{ml}$ of distilled water and 5-8 drops of Fehling's solution was added and heated. The brick red precipitate was formed. Hence reducing sugar was identified.

\section{Test for glycosides}

\section{Keller kiliani's test}

The plant extract $5 \mathrm{ml}$ is mixed with Glacial acetic acid, few drops of Ferric chloride and concentrated sulphuric acid are added and observed for reddish brown colouration at the junction of two layers and the bluish green colour in the upper layer was formed. It indicates the presence of glycosides.

\section{Test for saponins}

The plant extract $50 \mathrm{ml}$ was diluted with $20 \mathrm{ml}$ of distilled water and it was agitated in a graduated cylinder for $15 \mathrm{~min}$. The formation of $1 \mathrm{~cm}$ layer of foam showed the presence of saponins.

\section{Test for flavonoids}

\section{Alkaline reagent test}

$1 \mathrm{ml}$ of the plant extract and a few drops of dilute sodium hydroxide were added. An intense yellow colour was produced which become colourless on addition of a few drops of dilute acid indicates the presence of flavonoids.

\section{Test for phenolic compounds}

The plant $5 \mathrm{ml}$ was dissolved in distilled water. Then few drops $1 \%$ lead acetate was added. A bulky white precipitate was formed, which indicates that the presence of phenolic compounds.

\section{Antibacterial activity}

\section{Collection of microorganisms and preparation of inoculum}

Staphylococcus aureus, Salmonella typhi, Escherichia coli, Entrococcus. feacalis, test bacteria were obtained from Department of Biotechnology, Periyar University, Salem, Tamil Nadu, India. Laboratory bacterial strains were used as test organisms. The bacteria were incubated on a nutrient agar slant (Stationary culture) for $48 \mathrm{~h}$ at 37 followed by inoculation in Nutrient Agar medium.

\section{Disc diffusion method}

Disc diffusion method was used to test the antibacterial activity of the extracts against the bacteria strains. The leaf extract were used for studying their antibacterial activity. A loopful of bacterial strains were inoculated into $5 \mathrm{ml}$ of nutrient broth and incubated for $24 \mathrm{~h}$ at 37 to get active strain by using disc diffusion method. Nutrient Agar plates were prepared by pouring $20 \mathrm{ml}$ of media into sterile Petri plates. The plates were allowed to solidify for $5 \mathrm{~min}$ and $0.1 \%$ inoculums suspension was swabbed uniformly and the inoculums were allowed to dry for $5 \mathrm{~min}$. The different concentrations of extracts $(25,50$, and $75 \mathrm{mg} /$ disc $)$ were loaded on $5 \mathrm{~mm}$ sterile individual discs. The loaded discs were placed on the surface of medium and the compound was allowed to diffuse for $5 \mathrm{~min}$ and the plates were kept for incubation at $37^{\circ} \mathrm{C}$ for $24 \mathrm{~h}$. Streptomycin $(10 \mu \mathrm{g} / \mathrm{disc})$ was used as control. At the end of incubation, inhibition zones formed around the disc were measured with transparent ruler in millimeter. These studies were performed in triplicate.

\section{RESULTS AND DISCUSSION}

\section{Phytochemical analysis}

Show the table 1 results of Preliminary phytochemical screening of Ipomoea indica leaf exextracts; triterpenes, flavonoids, saponin, and glycosides were found in the aqueous and methanol extract while alkaloids and reducing sugar were found only in the methanol extract. However, tannin, and steroid, was found only aqueous extract. However Phenolic compound, Anthroquinones and alkaloids were absent in aqueous extract. Steroid, tannin, Phenolic compound, and Anthroquinones are absent in methanol extract.

\section{Table 1: Phytochemical profile of aqueous and methanol leaf extracts of Ipomoea indica}

\begin{tabular}{lll}
\hline Compound & Methanol extract & Water extract \\
\hline Alkaloid & + & - \\
Flavnoid & + & + \\
Steroid & - & + \\
Tanin & - & + \\
Terpinoid & + & + \\
Glycocide & + & + \\
Phenolic compound & - & - \\
Anthroquinones & - & - \\
Reducing sugar & + & - \\
Saponin & + & + \\
\hline
\end{tabular}

\section{Antibacterial activty}

The antibacterial activity of methanol and aqueous extract of Ipomoea indica and control streptomycin were tested for different strains of bacteria and zone of inhibition was recorded in millimeter. Show the table 2.1 water extract the large inhibition zone against bacterial stains Salmonella typhi $(26 \mathrm{~mm})$, Staphylococcus aureus(8 $\mathrm{mm})$, Enterococcus feacalis (8 $\mathrm{mm})$, Escherichia coli $(5 \mathrm{~mm})$ in comparison with control drug streptomycin which inhibition zone against Salmonellatyph $i(12 \mathrm{~mm})$, Staphylococcusaureus $(12 \mathrm{~mm})$, Enterococcus feacalis $(10 \mathrm{~mm})$, Escherichia coli $(13 \mathrm{~mm})$.

Show the table 2.1 for methanolic extract of leaves of $I$. indica showed the large inhibition zone against bacterial stains Salmonella typhi $(6 \mathrm{~mm})$, 
Staphylococcus aureus (6 mm), Enterococcus feacalis (5 mm), Escherichia coli(4 mm) in comparison with control drug streptomycin which inhibition zone against Salmonella typhi (8 mm), Staphylococcusaureus (10 mm), Enterococcus feacalis (6 mm),), Escherichia coli(12 mm).

Table 2.1: Showing antibacterial inhibition zone of water extract of leaves of Ipomoea indica

\begin{tabular}{|c|c|c|c|c|c|}
\hline \multirow[t]{2}{*}{ S. No. } & \multirow[t]{2}{*}{ Name of the organisms } & \multicolumn{4}{|c|}{ Zone of Inhibition values in $\mathrm{mm}$} \\
\hline & & control & $25 \mu \mathrm{l}$ & $50 \mu l$ & $75 \mu \mathrm{l}$ \\
\hline 1 & Staphylococcus aureus & 12 & 6 & 7 & 8 \\
\hline 2 & Salmonella typhi & 12 & 10 & 12 & 26 \\
\hline 4 & Escherichia coli & 13 & 3 & 4 & 5 \\
\hline 4 & Enterococcus faecalis & 10 & 4 & 5 & 8 \\
\hline
\end{tabular}

Table 2.2: Showing antibacterial inhibition zone of methanol extract of leaves of Ipomoea indica

\begin{tabular}{|c|c|c|c|c|c|}
\hline \multirow[t]{2}{*}{ S. No. } & \multirow[t]{2}{*}{ Name of the organisms } & \multicolumn{4}{|c|}{ Zone of Inhibition values in $\mathrm{mm}$} \\
\hline & & Control & $25 \mu \mathrm{l}$ & $50 \mu \mathrm{l}$ & $75 \mu l$ \\
\hline 1 & Staphylococcus aureus & 10 & 4 & 5 & 6 \\
\hline 2 & Salmonella typhi & 8 & 4 & 5 & 6 \\
\hline 3 & Escherichia coli & 12 & 2 & 3 & 4 \\
\hline 4 & Enterococcus faecalis & 6 & - & 4 & 5 \\
\hline
\end{tabular}

\section{CONCLUSION}

This present study suggests that the aqueous extract of the Ipomoea indica leaves possesses bioactive compounds with antibacterial activity against the bacterial strains. It is also suggest that $I$. indica used for the treatment of disease caused by some bacteria tested in this study. These I. indica plant extract can be used to formulate the new antibacterial drugs against the diseases.

\section{ACKNOWLEDGEMENT}

I thank to department of botany periyar university, salem, Tamilnadu, India

\section{AUTHORS CONTRIBUTIONS}

All the author have contributed equally

\section{CONFLICT OF INTERESTS}

Declared none

\section{REFERENCES}

1. Kumari SS, Rao SVS, Misra S, Murty US. Antifungal activity of Turbinaria conoides and evaluation for the effective concentration against the infection of Beauveria bassiana in silkworm larvae. Res J Microbiol 2011;6:115-23.

2. Rao GB, Umamaheshwara Rao P, Sambasiva Rao E, Mallikarjuna Rao T, Pranitha VS. Evaluation of in vitro antibacterial activity and anti-inflammatory activity for different extracts of Rauwolfia tetraphylla L. root bark. Asian Pacific J Trop Biomed 2012;2:818-21.

3. Padmaa MP, Leena JP, Angelin ST. Genius salacia: a comprehensive review. J Nat Remed 2010;8:116-31.

4. Vander Waaij D, Nord CE. The fluoroquinolone antibacterials: past, present and future perspectives. Int J Antimicrob Agents 2000;16:191-7.

5. Krishnaiah D, Devi T, Bono A, Sarbatly R. Studies on phytochemical constituents of six Malaysian medicinal plants. J Med Plants Res 2009;3:67-72.

6. Krishnaiah D, Sarbatly R, Bono A. Phytochemical antioxidants for health and medicine-a move towards nature. Biotechnol Mol Biol Rev 2007;1:97-104.

7. Edeoga HO, Okwu DE, Mbaebie BO. Phytochemical constituents of some Nigerian medicinal plants. Afr J Biotech 2005;4:685-8.

8. Okunade AL. Review ageratum conyzoides L. (Asteraceae). Fitoterapia. 2002;73:1-16

9. Porwal Omji, Saxena Rubha, Nanjan Moola Joghee. Antioxidant activity of Ipomoea leari. J Drug Delivery Ther 2012;2:79-85. 